\title{
Budowa i modernizacja linii kolejowych w ramach sieci TEN-T
}

\begin{abstract}
(Materiat do artykutu przedstawiono w formie prezentacji na Międzynarodowych Targach Poznańskich - Transporta 2009 - Transport Szynowy XXI wieku dla Polski.)
\end{abstract}

Transeuropejskie sieci transportowe i paneuropejskie korytarze transportowe mają stanowić element służący osiagnięciu wzrostu gospodarczego i integracji społecznej w Europie. Sektor transportu musi spełniać większe wymagania w zakresie mobilności społeczeństw poszczególnych krajów. Przebieg paneuropejskich korytarzy ukształtowany został podczas trzech Konferencji Ministrów: w Pradze 1991r., na Krecie 1994r. i w Helsinkach 1997r. . Aktualnie istnieje 10 korytarzy transportowych.

Przez teren Polski przebiegają 4 korytarze transportowe:

\section{Korytarz I}

Helsinki - Tallinn - Riga - Kowno - Trakiszki - Suwałki - Sokółka - Białystok -

- Warszawa

z odgałęzieniem:

Riga - Kaliningrad - Braniewo - Malbork - Gdańsk

Korytarz II:

Berlin - Rzepin - Poznań - Warszawa - Siedlce Łuków - Terespol - Mińsk -

- Moskwa - Nizhny Nowgorod z odgałęzieniami:

Poznań Górczyn - Poznań Franowo - Swarzędz oraz

Łowicz - Skierniewice - Pilawa - Łuków

\section{Korytarz III:}

Berlin - Bielawa Dolna - Wegliniec - Legnica Wrocław - Opole - Katowice -

- Kraków - Rzeszów - Przemyśl - Medyka - Lwów Kijów

z odgałęzieniami:

Drezno - Zgorzelec - Węgliniec

Korytarz IV

Gdańsk - Malbork - Warszawa - Idzikowice Zawiercie - Katowice - Bielsko B. -

- Zwardoń - Żilina - Bratysława z odgałęzieniami:

Tczew - Bydgoszcz - Inowrocław - Tarnowskie Góry - Chorzów Batory - Katowice oraz:

Pszczyna - Zebrzydowice - Ostrava - Wiedeń

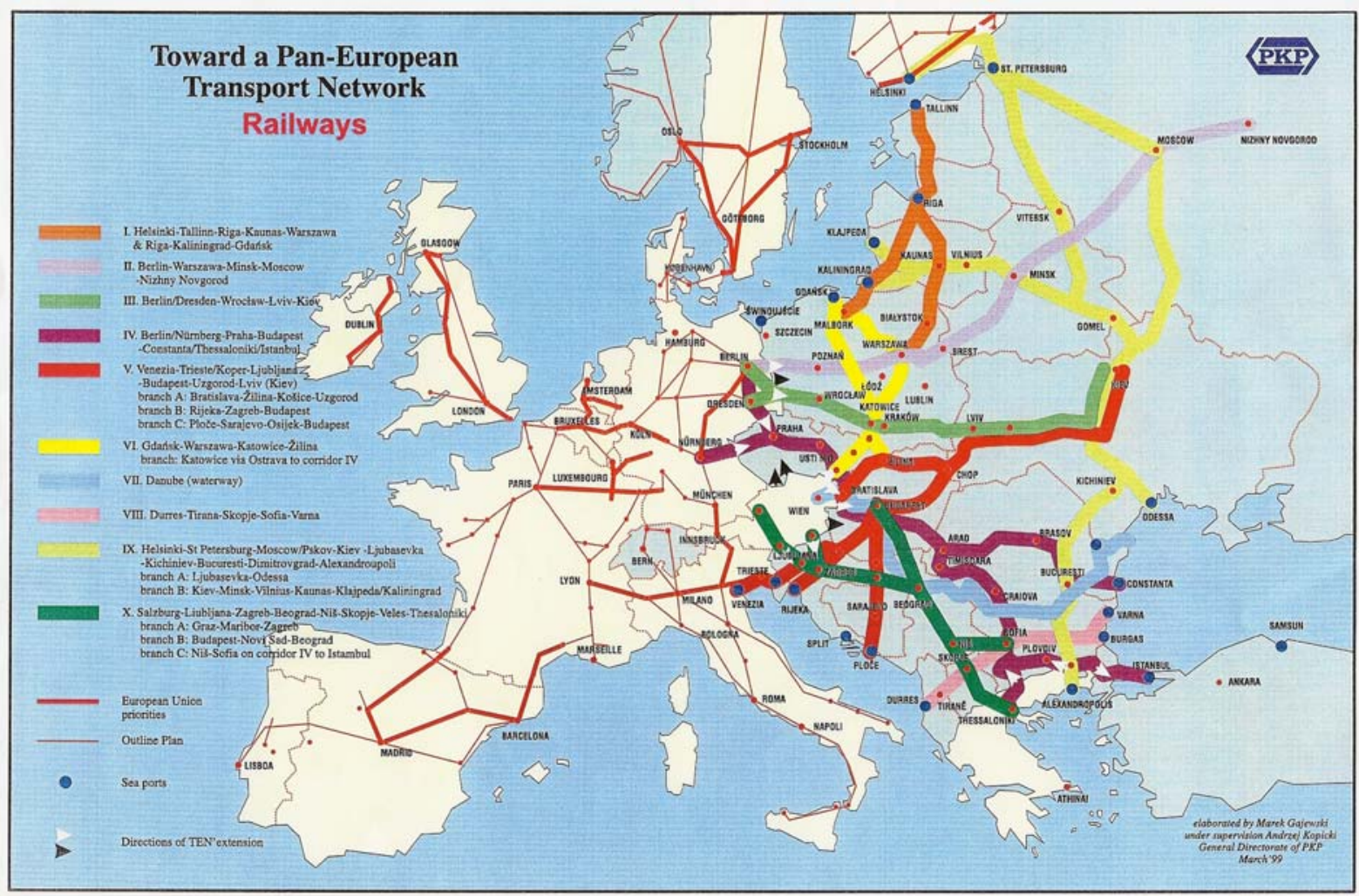


Na terenie Polski występuje korzystna sytuacja łączenia się i krzyżowania poszczególnych korytarzy. Istnieją propozycje rozszerzenia korytarzy na wschód i na południe (Trans-Syberia, Kaukaz i Azja Środkowa, Turcja i Morze Śódziemne). Transeuropejska sieć kolejowa składa się z Trans-European Sieci Kolei dużych prędkości, jak również transeuropejskich sieci kolei konwencjonalnej.

Transeuropejska sieć kolejowa winna spełniać jedną lub więcej z następujących funkcji:

- powinna odgrywać ważną rolę $\mathrm{w}$ dalekobieżnych przewozach pasażerskich

- gdzie możliwe, winna zapewniać połączenie z lotniskiem

- powinna umożliwiać dostęp do regionalnych i lokalnych sieci kolejowych

- powinna usprawniać prowadzenie ruchu towarowego - powinna odgrywać ważną rolę W transporcie kombinowanym

- powinna umożliwiać połączenia z portami morskimi i żeglugi śródlądowej

Normy dla transeuropejskiej sieci kolejowej ustalane są przez Europejską Agencję Kolejową (ERA) w postaci technicznych specyfikacji dla interoperacyjności.

Realizowane i zakładane plany modernizacji linii kolejowych w Polsce mają na celu:

usprawnienie przewozów pasażerskich i towarowych dostosowanie parametrów linii sieci transeuropejskiej do standardów europejskich (interoperacyjność i środowisko)

stworzenie warunków do skutecznego konkurowania na krajowym i międzynarodowym rynku transportowym

zapewnienie możliwości podróżowania z wykorzystaniem różnych środków transportowych

Konieczna jest zarówno modernizacja jak i budowa nowych odcinków linii kolejowych. Niezbędna jest budowa nowej linii Kolei Dużych Prędkości. W ramach modernizacji linii kolejowych wykonywane są prace w zakresie:

- układu torowego

- urządzeń zasilania energetycznego i podstacji trakcyjnych

- sieci trakcyjnej

- obiektów inżynieryjnych

- urządzeń sterowania ruchem kolejowym, w tym samoczynnej blokady liniowej

(Lokalne Centra Starowania Ruchem)

- urządzeń telekomunikacji

- samoczynnej sygnalizacji przejazdowej

- likwidacji przejazdów kolejowych

- peronów na stacjach i przystankach osobowych

- oświetlenia

- urządzeń wykrywania stanu awaryjnego taboru

- urządzeń do odstraszania (odpłaszania) zwierząt.

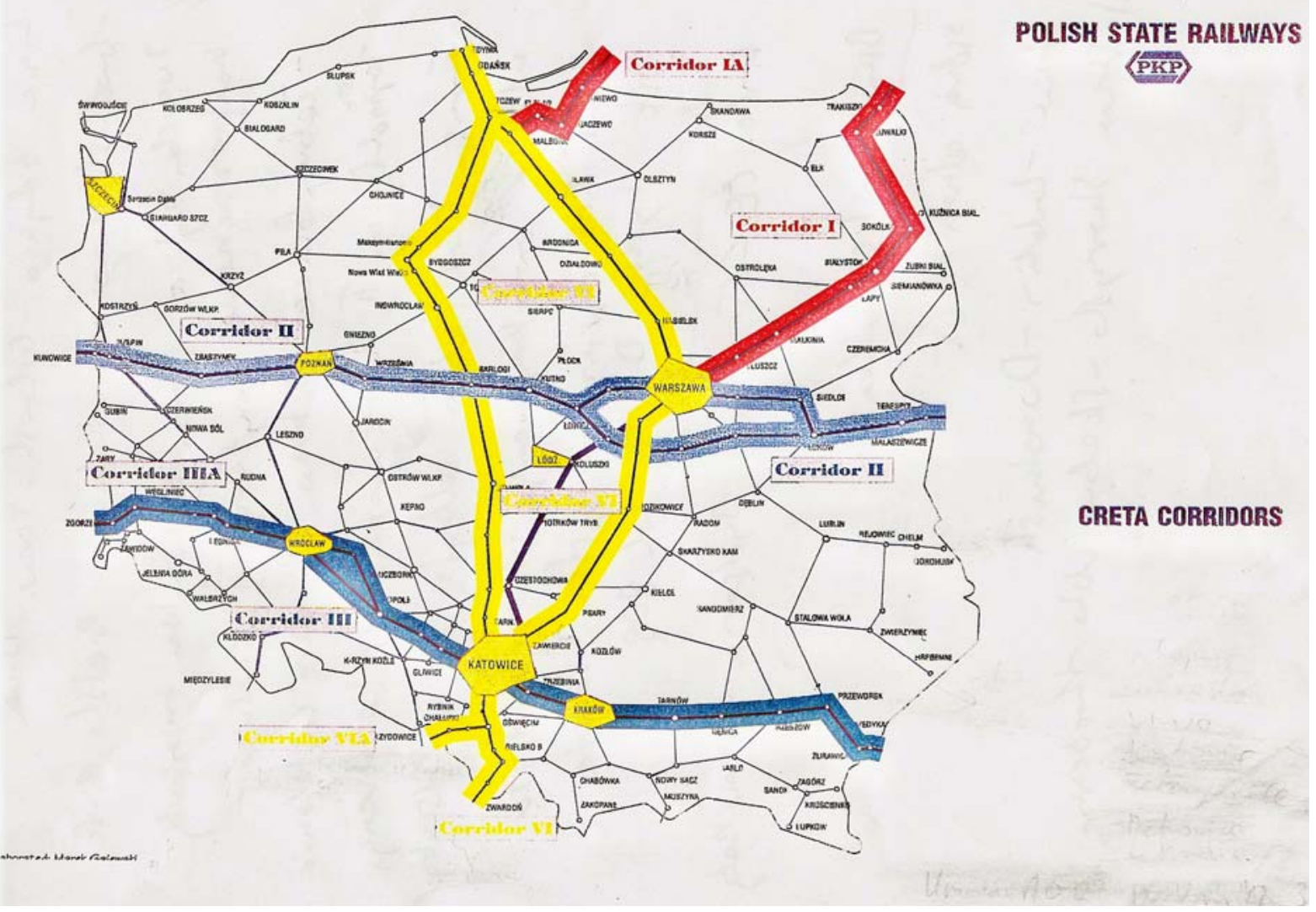


Modernizacja linii kolejowych finansowana jest ze środków UE (Fundusz Spójności, Program Operacyjny Infrastruktura i Środowisko, Fundusz TEN-T) oraz z budżetu państwa. Rada Europejska szczególne zainteresowanie wykazała korytarzami I i IV umieszczając je na liście 30 projektów priorytetowych, które winny rozpocząć się przed 2010r.

$\mathrm{Na}$ liście projektów współfinansowanych z Programu Operacyjnego Infrastruktura i Środowisko zatwierdzonego decyzją Komisji Europejskiej na lata $2007 \div$ 2013 znajdują się:

\section{- Korytarz I}

- Modernizacja linii E75 Rail Baltica Warszawa - Białystok - granica z Litwa, etap I, odcinek Warszawa Rembertów - Zielonka Tłuszcz - Sadowne (lista podstawowa)

- Modernizacja linii E75 Rail Baltica Warszawa - Białystok - granica z Litwą, etap I, odcinek Suwałki - Trakiszki - granica z Litwą (lista podstawowa).

- Korytarz III

- Modernizacja linii E30 etap II, na odcinku Zabrze - Katowice - Kraków (lista podstawowa)

- Modernizacja linii E30 etap II, na odcinku Rzeszów - granica państwa (lista podstawowa)

- Modernizacja linii E30, etap II, na odcinku Bielawa Dolna - Horka: budowa mostu przez Nysę Łużycką oraz elektryfikacja (lista podstawowa)

- Modernizacja linii E30, etap II. Wdrożenie ERTMS w Polsce na odcinku Legnica Wrocław - Opole - w części ETCS (lista podstawowa)

- Modernizacja linii E30, etap II. Pilotażowe wdrożenie ERMTS w Polsce na odcinku Legnica - Węgliniec - Bielawa Dolna - w części ETCS II (lista podstawowa)

- Modernizacja linii E30, etap II, Pilotażowe wdrożenie ERTMS w Polsce na odcinku Legnica - Węgliniec - Bielawa Dolna w części GSM - R (lista podstawowa)

- Modernizacja linii E30/CE30, etap II, na odcinku Opole - Gliwice - Zabrze (lista podstawowa)

- Modernizacja linii E30/CE30 odcinek Kraków - Rzeszów (lista rezerwowa)

$\mathrm{Na}$ liście projektów współfinansowanych z Funduszu TEN-T zatwierdzonego na lata $2007 \div 2013$ znajdują się:
- Korytarz III

- Modernizacja linii E30/CE30 na odcinku Kraków - Medyka - granica państwa

- Korytarz VI

- Modernizacja linii CE65 Tczew - Bydgoszcz Tarnowskie Góry - Pszczyna

- Modernizacja i rozbudowa Warszawskiego Węzła Kolejowego

Na liście projektów współfinansowanych z Funduszy ISPA/FS znajdują się:

- Korytarz I

- Pomoc techniczna dla przygotowania projektu „Modernizacja linii E75 na odcinku Warszawa - Białystok - Suwałki - Trakiszki granica państwa (Rail Baltica)

- Korytarz II

- Modernizacja linii E20 na odcinku Mińsk Maz. - Siedlce

- Modernizacja linii E20 Rzepin - granica państwa

- Modernizacja linii E20 Siedlce -Terespol etap I

- Modernizacja linii E20 na odcinku Warszawa - Rzepin oraz CE20 na odcinku Łowicz Skierniewice - Łuków

- Projekty modernizacyjne Poznańskiego Węzła Kolejowego

- Korytarz III

- Pomoc techniczna dla przygotowania projektu „Modernizacja linii kolejowej E30/CE30 na odcinku Opole - Katowice - Kraków

- Modernizacja linii E30 na odcinku Węgliniec Zgorzelec i Weggliniec -Bielawa Dolna

- Modernizacja zachodniego odcinka linii E30 zlokalizowanego pomiędzy Legnicą a Węglińcem

- Korytarz VI

- Modernizacja linii E65, odcinek Warszawa Gdynia, etap I

- Modernizacja linii E65, odcinek Warszawa Gdynia, etap II

- Modernizacja linii E65, odcinek Warszawa Gdynia, etap III

- Modernizacja linii E65 na odcinku Grodzisk Mazowiecki - Katowice

Zebrzydowice/Zwardoń - granica państwa

- Pomoc techniczna dla modernizacji linii E65 na odcinku Warszawa - Działdowo Gdynia 

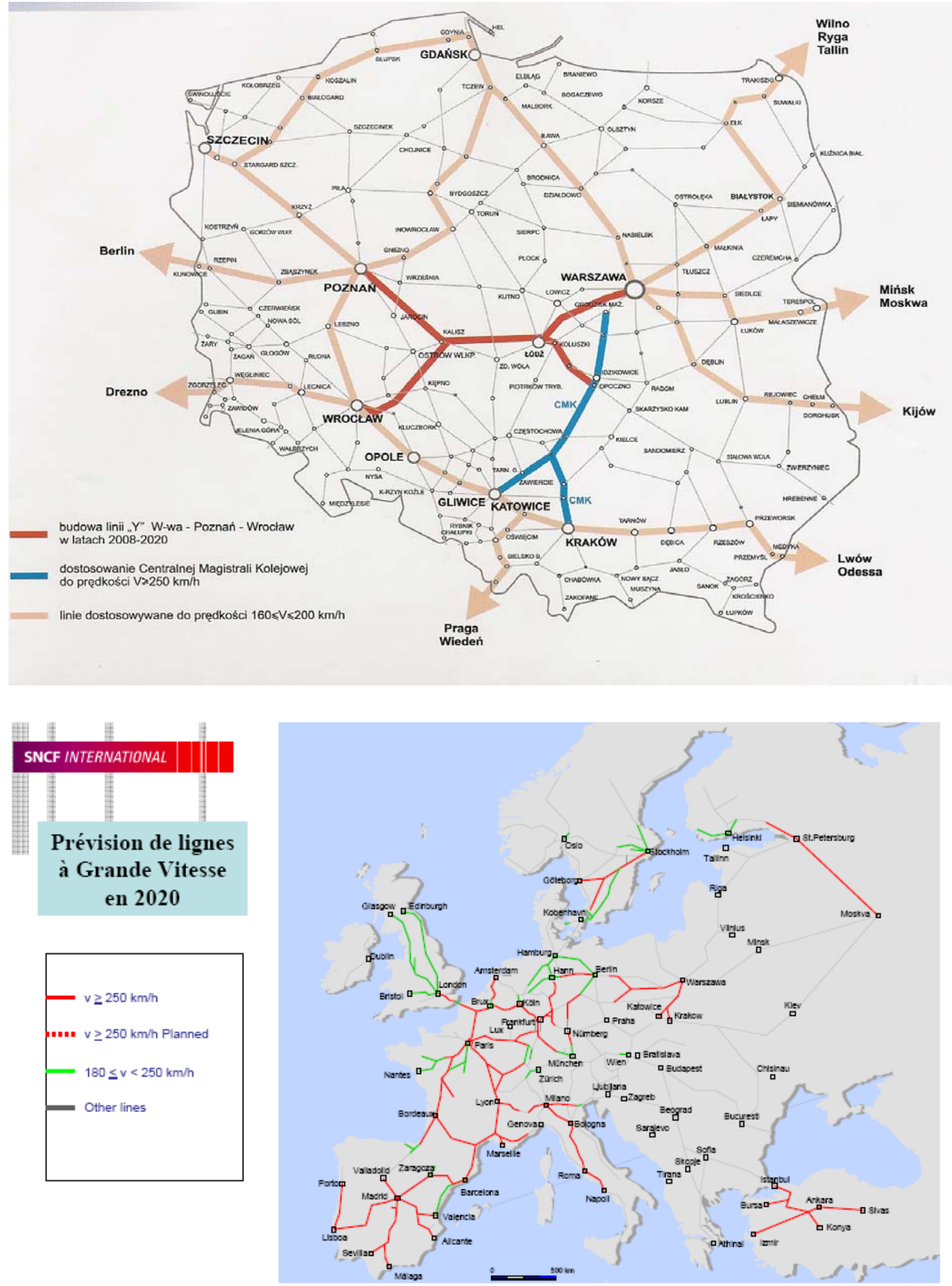

SNCF 
Zadania finansowane $\mathrm{z}$ udziałem ISPA/FS w większości zostały już zrealizowane. Efektem modernizacji linii jest umożliwienie kursowania pociagów pasażerskich

z prędkością max. $160(200) \mathrm{km} / \mathrm{h}$ przy dopuszczalnym nacisku na oś 22,5 ton.

Odrębny problem to włączenie Polskich Linii Kolejowych do transeuropejskiego systemu kolei dużych prędkości. Warunki umożliwiające przystosowanie do kursowania pociaggów z max. prędkością $250 \mathrm{~km} / \mathrm{h}$ (i więcej) posiada jedynie CMK (część Korytarza VI). Możliwości te należałoby jak najszybciej urzeczywistnić. Konieczne jest konsekwentne realizowanie planu budowy „Y" łączącego Warszawę

i Łódź z Poznaniem i Wrocławiem. Jest to olbrzymie wyzwanie. Konieczne będzie wybranie optymalnego wariantu przebiegu trasy z uwzględnieniem połączeń z liniami konwencjonalnymi, a w szczególności wprowadzenia do węzłów w Warszawie, Łodzi, Poznaniu i Wrocławiu.

W opracowaniu wykorzystano upublicznione informacje Ministerstwa Infrastruktury, PKP S.A. , PKP PLK S.A., SNCF
Z udziałem funduszy UE zostanie przygotowane studium wykonalności i projekt wstępny. Aby dotrzymać zakładanego terminu podjęcia ruchu (2020rok) pierwsze prace budowlane muszą być podjęte w $2013 \div 2014$ roku. Do rozwiązania zostaje wiele problemów dotyczących nawierzchni, sieci trakcyjnej, zasilania energetycznego, systemu sterowania ruchem kolejowym, łączności itp. Również szczególnie trudne zagadnienie to punkty styku $\mathrm{z}$ koleją konwencjonalną.

Na kolejach Zachodniej Europy cykl budowy KDP od „pomysłu” trwa $13 \div 14$ lat. Oby w „,naszej rzeczywistości” też dotrzymać podobnego terminu realizacji.

Uruchomienie linii „Y” i znaczace podwyższenie szybkości max. na linii CMK, umożliwi stworzenie siatki szybkich połączeń krajowych i międzynarodowych $\mathrm{z}$ wykorzystaniem innych linii zmodernizowanych do szybkości 160/200 km/h. 